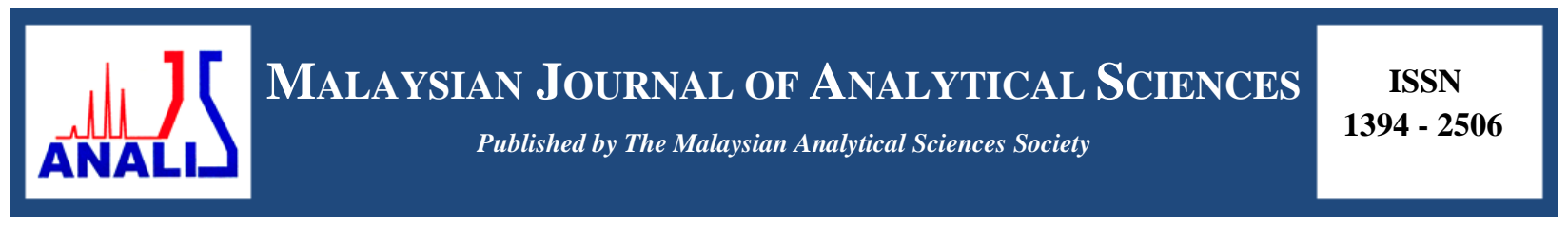

\title{
SALICYLATE-BASED PROTIC IONIC LIQUIDS AS A POTENTIAL ANTIOXIDANT
}

\section{(Cecair Ionik Protik Berasaskan Salisilat Berpotensi Sebagai Antioksida)}

\author{
Nur Afiqah Ahmad ${ }^{1}$, Khairulazhar Jumbri ${ }^{1,2 *}$, Anita Ramli ${ }^{1}$, Noraini Ghani ${ }^{1,2}$, Haslina Ahmad ${ }^{3}$ \\ ${ }^{I}$ Department of Fundamental and Applied Science \\ ${ }^{2}$ Centre of Research in Ionic Liquids (CORIL) \\ Universiti Teknologi PETRONAS, 32610 Seri Iskandar, Perak, Malaysia \\ ${ }^{3}$ Department of Chemistry, Faculty of Science, \\ Universiti Putra Malaysia, 43400 UPM Serdang, Selangor, Malaysia \\ *Corresponding author: khairulazhar.jumbri@utp.edu.my
}

Received: 19 August 2018; Accepted: 20 May 2019

\begin{abstract}
Salicylate-based protic ionic liquids (PILs) were synthesised, characterised and assessed in this study for potential antioxidant in drug design. The synthesised PILs were known as 3-dimethylamino-1-propanol salicylate (3DMAPS) and 3-diethylamino-1propanol salicylate (3DEAPS). Proton nuclear magnetic resonance $\left({ }^{1} \mathrm{HNMR}\right)$, Fourier transformation infrared spectroscopy (FTIR) and thermogravimetric analysis (TGA) were used to characterise the synthesised PILs. Furthermore, the antioxidant activity of the synthesised PILs was determined using the 2,2-diphenyl-1-picrylhydrazyl (DPPH) free radical assay. Both 3DMAPS and 3DEAPS showed a good antioxidant activity compared to parent acid (salicylic acid) as these two compounds could scavenge $20 \%$ of DPPH free radical at a concentration of $66.76 \pm 0.09 \mu \mathrm{M}$ and $27.27 \pm 0.10 \mu \mathrm{M}$, respectively.
\end{abstract}

Keywords: protic ionic liquids, salicylic acid, radical scavenging, free radical, DPPH assays

\section{Abstrak}

Cecair ionik protik (PILs) berasaskan salisilat disintesis, dicirikan dan dinilai untuk potensi antioksidan dalam reka bentuk dadah. Dua PILs iaitu 3-dimetilamino-1-propanol salisilat (3DMAPS) dan 3-diethilamino-1-propanol salisilat (3DEAPS) telah berjaya disintesis. Proton resonans magnetik nuklear $\left({ }^{1} \mathrm{HNMR}\right)$, spektroskopi transformasi inframerah (FTIR) dan analisis termogravimetrik (TGA) digunakan untuk pencirian PIL yang di sintesis. Tambahan pula, aktiviti antioksidan PIL ditentukan dengan menggunakan ujian radikal bebas 2,2-difenil-1-pikrilhidrazil (DPPH). Kedua-dua 3DMAPS dan 3DEAPS menunjukkan aktiviti antioksidan yang baik berbanding dengan asid induk (asid salisilat) kerana kedua-dua sebatian ini boleh membakar 20\% radikal bebas DPPH masing-masing pada kepekatan $66.76 \pm 0.09 \mu \mathrm{M}$ dan $27.27 \pm 0.10 \mu \mathrm{M}$.

Kata kunci: cecair ionic protik, asid salisilik, perangkap radikal, radikal bebas, ujian DPPH

\section{Introduction}

Ionic liquid (IL) is a molten salt with a melting point below $100{ }^{\circ} \mathrm{C}$. This compound can exist as a liquid or solid form at room temperature [1]. Furthermore, IL is also known as 'green solvent' due to negligible vapour pressure [2]. A growing trend has been seen in the development of IL in various applications such as organic synthesis, biocatalysis [3], electrochemistry [4], extraction [5] and in pharmaceutical [6]. IL can be classified into two classes; aprotic and protic ionic liquids. Protic ionic liquids (PILs) are a new family member of IL with available polar proton attached on the cation structure, which could lead to hydrogen bonding interaction [7]. Besides, these 
compounds can be easily synthesised by mixing an equimolar solution of Brønsted acid and Brønsted base [8]. The formation of PILs is highly depending on the transfer of proton from the Brønsted acid to Brønsted base [7].

Over the past few years, PILs have attracted increasing attention and have been considered for plethora of applications such as electrochemistry [9], fuel cell [10] and drug delivery [11]. In drug delivery, PILs are used in membrane transport due to the tuneable degree of ionicity. However, to the best of our knowledge, only a few studies have been dedicated to synthesise PILs with specific biological applications [11-13]. In this study, salicylic acid was used as the anion based PILs for potential antioxidant. Salicylic acid is one of the phenolic acid derivatives reported to display multiple biological applications such as antioxidant activity, antimicrobial and anti-inflammatory [14]. In addition, low solubility of this acid in water can cause insufficient performance of the salicylic acid. Therefore, the modification of salicylic acid in the form of IL is one of the alternative ways to enhance the performance of this drug compound.

\section{Materials}

\section{Materials and Methods}

3-dimethylamino-1-propanol (purity 99\%), methanol and salicylic acid were kindly supplied by Merck Sdn. Bhd company (Darmstadt, Germany). 3-diethylamino-1-propanol was purchased from Acros (Shah Alam, Malaysia). All of these chemicals were used as received without further purification.

\section{Synthesis and characterization of PILs}

Protic ionic liquids (PILs) were synthesised by neutralisation reaction. An equimolar of salicylic acid (0.05 mol, 6.9 g) was added to equimolar amount of different base namely 3-dimethylamino-1-propanol and 3-diethylamino-1propanol $(5.9 \mathrm{~mL}$ and $7.4 \mathrm{~mL}$, respectively). The base was placed into two-neck round bottom flask immersed in ice bath and equipped with a reflux condenser. Since the reaction is exothermic, the temperature was maintained around $0-5{ }^{\circ} \mathrm{C}$ while an acid was added drop wise. Then, the solvent (methanol) was removed by heating the mixture at 50 ${ }^{\circ} \mathrm{C}$ under vacuum using rotary evaporator for 3 hours. Afterwards, the structure and purity of PILs were characterised using Bruker Avance $500 \mathrm{MHz}{ }^{1} \mathrm{HNMR}$ spectrometer. The structure of PILs was further characterised via Shimadzu FTIR at wavenumber of $4000 \mathrm{~cm}^{-1}$ to $400 \mathrm{~cm}^{-1}$ to determine amine and carbonyl functional groups. The thermal stability of PILs was determined using PerkinElmer, Pyris V-3.81 thermogravimetric analyser.

\section{Antioxidant activity}

The methods for antioxidant activity was obtained from Brand-Williams [15] using 2,2-diphenyl-1-picrylhydrazyl (DPPH) free radical assay with slight modifications. PILs with various final concentrations $(10-100 \mu \mathrm{M})$ in methanol were added into DPPH solution in methanol $(60 \mu \mathrm{M}, 3.9 \mathrm{~mL})$. After that, the mixture was incubated in dark condition for $30 \mathrm{~min}$ at room temperature. The decrease in absorbance was monitored using UV-Vis at wavelength of $517 \mathrm{~nm}$. The antioxidant activity was calculated using equation 1 as shown below:

$$
\operatorname{AA}(\%)=\left(\mathrm{A}_{0}-\mathrm{A}_{1}\right) / \mathrm{A}_{0} \times 100 \%
$$

where $\mathrm{A}_{0}$ is the absorbance of the DPHH without PILs and $\mathrm{A}_{1}$ is the absorbance of the sample (PILs and DPPH) at $517 \mathrm{~nm}$.

\section{${ }^{1}$ HNMR}

\section{Results and Discussion}

The ${ }^{1}$ HNMR was used to determine the structure and purity of the synthesised PILs. Figure 1 shows the ${ }^{1}$ HNMR spectrum of 3DMAPS and 3DEAPS PILs, respectively.

\section{3-Dimetylamino propanol salicylate (3DMAPS)}

Pale yellow liquid (Yield: $94.5 \%){ }^{1} \mathrm{H} \mathrm{NMR}\left(\mathrm{CDCl}_{3}\right) \delta(\mathrm{ppm}): 1.94(\mathrm{~m}, 2 \mathrm{H}), 2.79(\mathrm{~s}, 6 \mathrm{H}), 3.26(\mathrm{t}, 2 \mathrm{H}), 3.83(\mathrm{t}, 2 \mathrm{H})$, $6.82(\mathrm{t}, 1 \mathrm{H}), 6.99(\mathrm{~d}, 1 \mathrm{H}), 7.37(\mathrm{t}, 1 \mathrm{H}), 7.85(\mathrm{~d}, 1 \mathrm{H})$. 


\section{3-Diethylamino propanol salicylate (3DEAPS)}

Pale yellow liquid (Yield: 99.5\%) ${ }^{1} \mathrm{H}$ NMR $\left(\mathrm{CDCl}_{3}\right) \delta(\mathrm{ppm}): 1.25(\mathrm{t}, 6 \mathrm{H}), 1.73(\mathrm{~m}, 2 \mathrm{H}), 3.09(\mathrm{~m}, 6 \mathrm{H}), 3.71(\mathrm{t}, 2 \mathrm{H})$, $6.82(\mathrm{dd}, 2 \mathrm{H}), 7.29(\mathrm{~d}, 1 \mathrm{H}), 7.85(\mathrm{~d}, 1 \mathrm{H})$.
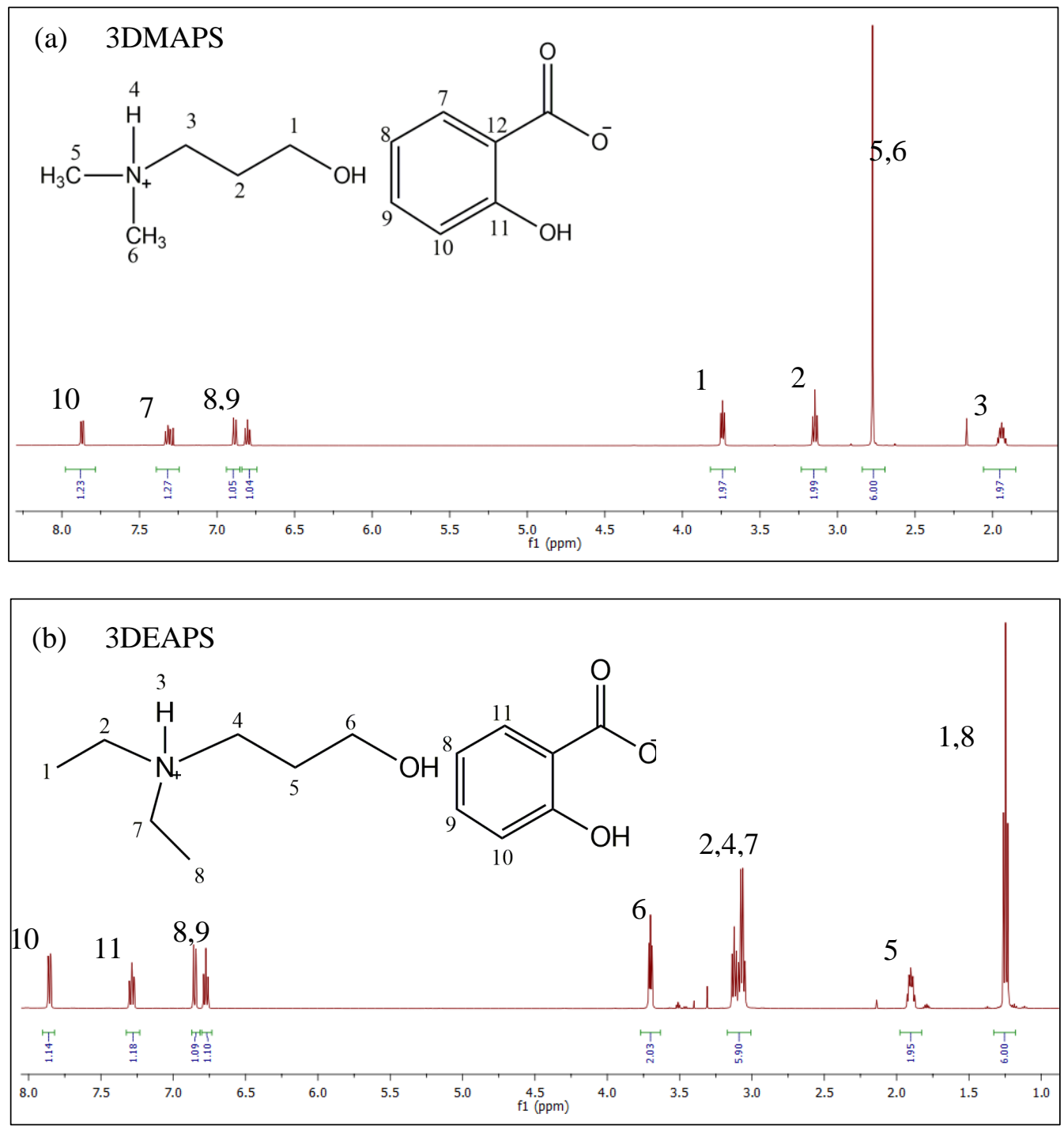

Figure 1. ${ }^{1} \mathrm{H}$ NMR of synthesized PILs (a) 3DMAPS, (b) 3DEAPS

\section{FTIR spectroscopy}

The synthesised PILs were further characterised using Fourier transform infrared spectroscopy (FTIR). From the FTIR spectra, the vibration peak of the amine and carbonyl functional group was studied to determine the formation of the PILs. Figure 2 ( $a$ and $b$ ) shows the FTIR spectra of synthesised PILs with neat alkanolamine and phenolic acid. It can be seen that neat phenolic acid (salicylic acid, SA) spectrum has a sharp peak at wavenumber of 1650.77 $\mathrm{cm}^{-1}$. This indicated the vibration frequency of the carbonyl group $(\mathrm{C}=\mathrm{O})$ of carboxylic acid [16].

Meanwhile, there was no - NH bending vibration detected in the neat 3DMAP and 3DEAP due to the absence of $\mathrm{NH}$ bond in the tertiary alkanolamine (3DMAP and 3DEAP). However, in the 3DMAPS spectrum, a new weak peak was observed at $1625.70 \mathrm{~cm}^{-1}$ and at $1626.18 \mathrm{~cm}^{-1}$ in 3DEAPS, which denotes the vibration peaks of 
protonated tertiary amine $-\mathrm{NH}^{+}[17,18]$. On top of that, the carboxylate anion $\left(-\mathrm{COO}^{-}\right)$was detected at 1377.408 and $1379.818 \mathrm{~cm}^{-1}$ in the spectrum of the 3DMAPS and 3DEAPS, respectively. Thus, it could be deduced that the resonance effect of the carboxylate anion had caused the shift of the peak as the hydrogen atom from hydroxyl group of the SA was transferred to the nitrogen atom of the tertiary alkanolamine [19]. The findings are in agreement with the results reported by other researchers [20,21].

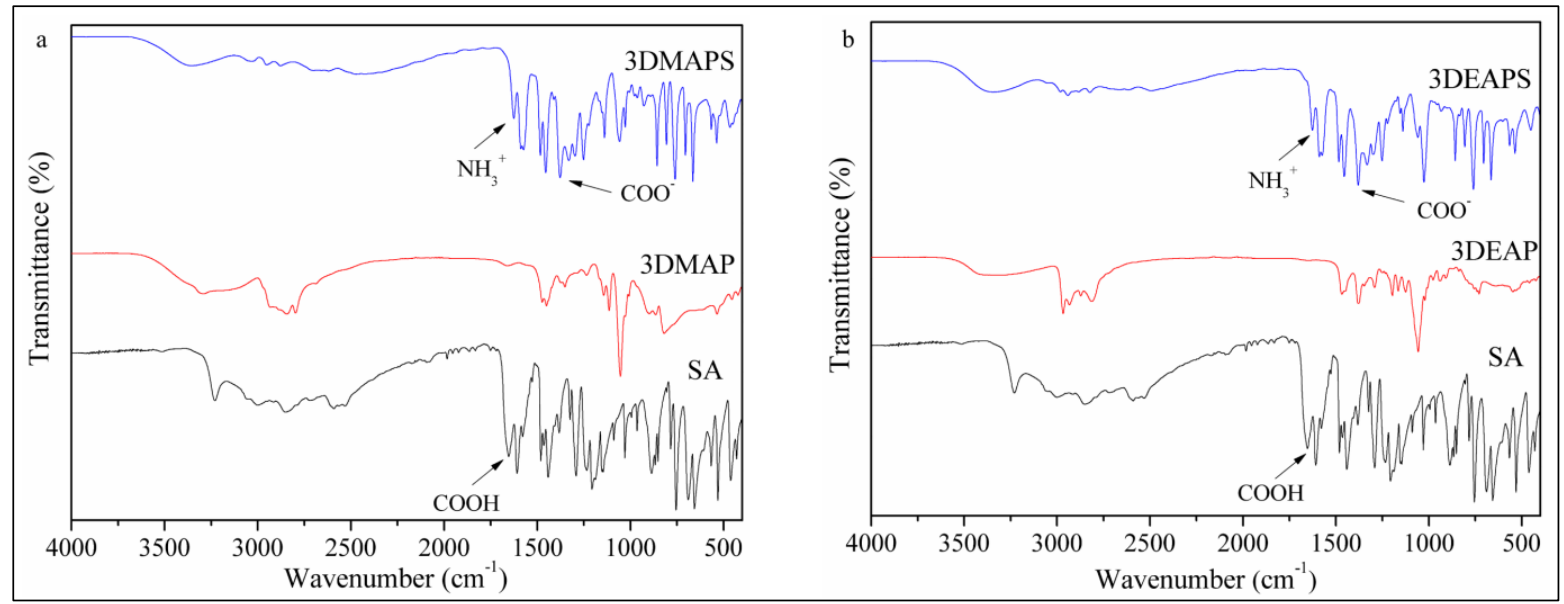

Figure 2. IR spectrum for 3DMAPS and 3DEAPS of synthesized PILs.

\section{Thermal stability}

Thermal decomposition temperature of the synthesised PILs was recorded ranging from $50{ }^{\circ} \mathrm{C}$ until $350{ }^{\circ} \mathrm{C}$. Figure 3 shows the thermograms of 3DMAPS and 3DEAPS PILs. As can been seen, the 3DMAPS has slightly higher thermal decomposition temperature $\left(\mathrm{T}_{\mathrm{d}}\right)$ than 3DEAPS $\left(190.70{ }^{\circ} \mathrm{C}\right.$ and $188.80{ }^{\circ} \mathrm{C}$, respectively). It could be concluded that the alkyl chain length only gave a small effect towards the thermal stability of PILs. This was because as the alkyl chain length increases from methyl to ethyl, the intermolecular Van der Waals force interaction also increased [22]. Hence, this led to the reduction of strength in intramolecular bonding [23]. Moreover, increasing alkyl chain length can form a more stable carbocation that helps the 3DEAPS to be easily decomposed [24]. Similar findings have been observed in other studies [23].

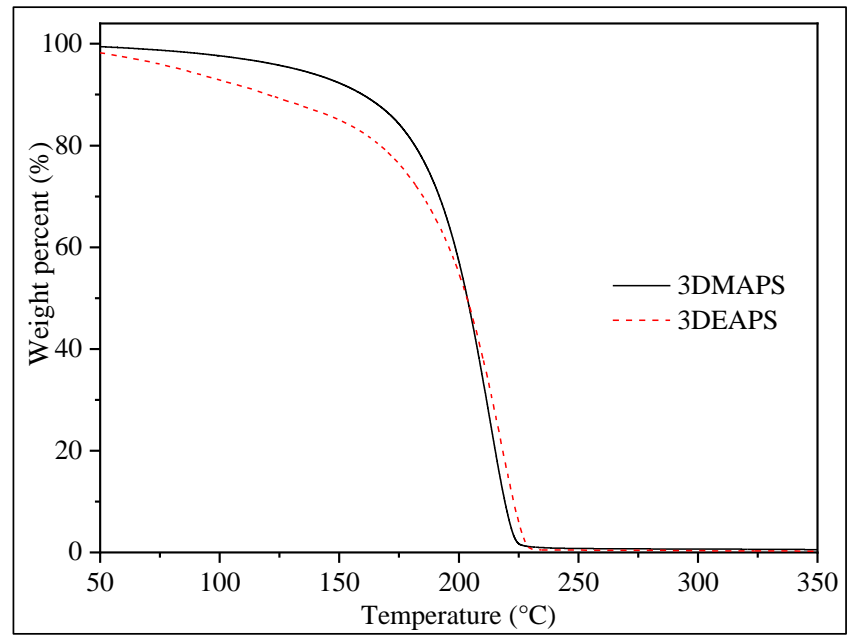

Figure3. Thermogravimetric trace PILs 


\section{Antioxidant activity}

The results of antioxidant activity were expressed in terms of $\mathrm{IC}_{20}$ value, which represent the effective concentration required to scavenge $20 \%$ of DPPH free radical. Low $\mathrm{IC}_{20}$ value indicates more effective antioxidant activity. The $\mathrm{IC}_{20}$ was calculated from the difference concentration of PILs and SA ranging from 10 to $100 \mu \mathrm{M}$. Table 1 shows the summarised $\mathrm{IC}_{20}$ value of synthesised PILs and parent acid (SA). From the results obtained, it can be seen that the $\mathrm{IC}_{20}$ of parent acid (SA) was not detected at the selected range of concentration. This was due to low effectiveness of SA towards the DPPH free radical. However, both PILs (3DMAPS and 3DEAPS) were able to scavenge $20 \%$ of free radical at concentration of $66.76 \pm 0.09 \mu \mathrm{M}$ and $27.27 \pm 0.10 \mu \mathrm{M}$, respectively, due to the huge number of active group $(\mathrm{OH}$ and $\mathrm{NH}$ group) present in the compound. The $-\mathrm{OH}$ and $-\mathrm{NH}$ transfer the hydrogen atom via hydrogen abstraction to stabilise DPPH free radical [25], hence increasing the antioxidant activity. Furthermore, by comparing these two PILs, 3DEAPS $(27.27 \pm 0.10 \mu \mathrm{M})$ was found to be a more effective antioxidant than 3DMAPS $(66.76 \pm 0.09 \mu \mathrm{M})$. This was because [3DEAP] ${ }^{+}$exhibited a more bulky structure than $[3 \mathrm{DMAP}]^{+}$(Figure 4 ), which could reduce the hinder of the radical scavenging by increasing the tendency of hydrogen abstraction at $-\mathrm{NH}$ group of the cation structure [26].

Table 1. $\mathrm{IC}_{20}$ value of PILs

\begin{tabular}{ll}
\hline Sample & $\mathbf{I C}_{\mathbf{2 0}}(\boldsymbol{\mu M})$ \\
\hline Salicylic Acid (SA) & ND \\
3DMAPS & $66.76 \pm 0.09$ \\
3DEAPS & $27.27 \pm 0.10$ \\
\hline
\end{tabular}

$\mathrm{ND}=$ not detected

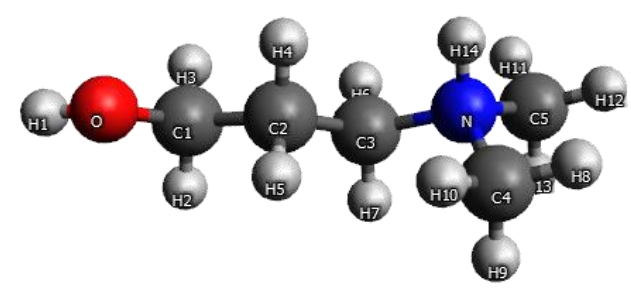

[3DMAP]

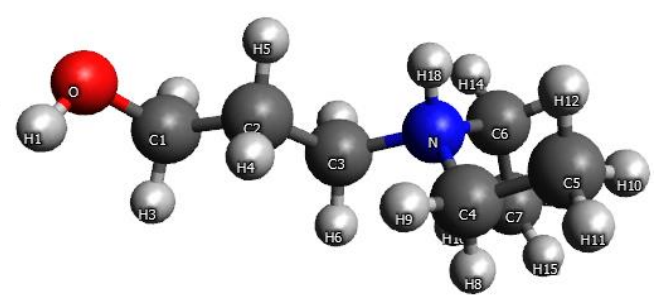

[3DEAP]

Figure 4. Structure of $[3 \mathrm{DMAP}]^{+}$and $[3 \mathrm{DEAP}]^{+}$

\section{Conclusion}

The 3DMAPS and 3DEAPS PILs have been successfully synthesised and characterised and their application as a potential antioxidant was determined. The synthesised PILs showed a remarkable antioxidant activity compared to that of parent acid (SA) due to the extra number of active group present $(-\mathrm{OH}$ and $-\mathrm{NH})$ in the structure. The presence of extra active group led to a high DPPH scavenging, thus increasing antioxidant activity. For future works, kinetics study and other antioxidant assays are suggested to be considered to further confirm the antioxidant activity of the synthesised compound. Besides, increasing in concentration could be carried out to determine the half maximal inhibition concentration $\left(\mathrm{IC}_{50}\right)$ value of the samples.

\section{Acknowledgement}

This research was funded by Short Term Internal Research Fund (STIRF 0153AA-F21), Universiti Teknologi PETRONAS. Nur Afiqah Ahmad acknowledges the UTP Graduate Assistantship (GA) scheme, Universiti Teknologi PETRONAS. 


\section{References}

1. Freemantle, M. (2010). An introduction to ionic liquids. Royal Society of Chemistry: pp. 1-2.

2. Stoimenovski, J., Dean, P. M., Izgorodina, E. I. and MacFarlane, D. R. (2012). Protic pharmaceutical ionic liquids and solids: Aspects of protonics. Faraday Discussions, 154(1): 335-352.

3. Yang, Z. and Pan, W. (2005). Ionic liquids: Green solvents for nonaqueous biocatalysis. Enzyme and Microbial Technology, 37(1): 19-28.

4. Hayouni, S., Robert, A., Ferlin, N., Amri, H. and Bouquillon, S. (2016). New biobased tetrabutylphosphonium ionic liquids: Synthesis, characterisation and use as a solvent or co-solvent for mild and greener Pd-catalyzed hydrogenation processes. RSC Advances, 6(114): 113583-113595.

5. Visser, A. E., Swatloski, R. P., Reichert, W. M., Mayton, R., Sheff, S., Wierzbicki, A. and Rogers, R. D. (2002). Task-specific ionic liquids incorporating novel cations for the coordination and extraction of $\mathrm{Hg}^{2+}$ and $\mathrm{Cd}^{2+}$ : Synthesis, characterisation, and extraction studies. Environmental Science and Technology, 36(11): 25232529.

6. Siodmiak, T., Piotr Marszall, M. and Proszowska, A. (2012). Ionic liquids: A new strategy in pharmaceutical synthesis. Mini-Reviews in Organic Chemistry, 9(2): 203-208.

7. Greaves, T. L. and Drummond, C. J. (2008). Protic ionic liquids: Properties and applications. Chemistry Reviews, 108(1): 206-237.

8. Kennedy, D. F. and Drummondt, C. J. (2009). Large aggregated ions found in some protic ionic liquids. Journal of Physical Chemistry B, 113(17): 5690-5693.

9. Gung, S. T., Sun, I. W., Ou-Yang, W. C., Su, S. G., Lin, M. W., Lai, C. A. and Lin, Y. C. (2012). Synthesis and characterisation of protic ionic liquids containing cyclic amine cations and tetrafluoroborate anion. Journal of the Iranian Chemical Society, 8(1): 149-165.

10. Yasuda, T. and Watanabe, M. (2013). Protic ionic liquids: Fuel cell applications. MRS Bulletin, 38(7): 560-566.

11. Stoimenovski, J. and MacFarlane, D. R. (2011). Enhanced membrane transport of pharmaceutically active protic ionic liquids. Chemical Communications, 47(41): 11429-11431.

12. Mirskova, A. N., Adamovich, S. N., Mirskov, R. G. and Voronkov, M. G. (2014). Pharmacologically active salts and ionic liquids based on 2-hydroxyethylamines, arylchalcogenylacetic acids, and essential metals. Russian Chemical Bulletin, 63(9): 1869-1883.

13. Pernak, J., Goc, I. and Mirska, I. (2004). Anti-microbial activities of protic ionic liquids with lactate anion. Green Chemistry, 6(7): 323-329.

14. Randjelović, D., Stojiljković, N., Laketić, D., Ilić, I., Randjelović, N., Veljković, S. and Sokolović, D. (2016). The beneficial biological properties of salicylic acid. Acta Facultatis Medicae Naissensis, 32(4): 259-265.

15. Brand-Williams, W., Cuvelier, M. E. and Berset, C. L. W. T. (1995). Use of free radical method to evaluate antioxidant activity. LWT - Food Science and Technology, 28(1): 25-30.

16. Jadrijević-Mladar Takac, M. and Vikić Topić D. (2004). FT-IR and NMR spectroscopic studies of salicylic acid derivatives . II . Comparison of 2-hydroxy- and 2 , 4- and 2,5-dihydroxy derivatives. Acta Pharmaceutica, 54(3): 177-191.

17. Sinsheimer, J. E. and Keuhnelian, A. M. (1966). Near-infrared spectroscopy of amine salts. Journal of Pharmaceutical Sciences, 55(11): 1240-1244.

18. Cook, D. (1964). Protonation site in organic bases from Infrared $\mathrm{X}-\mathrm{H}$ deformation modes. Canadian Journal of Chemistry, 42(10): 2292-2299.

19. Pavia, D. L., Lampman, G. M. and Kriz, G. S. (2010). Introduction to spectroscopy. Cengage Learning: pp. 370-372.

20. Puttipipatkhachorn, S., Nunthanid, J., Yamamoto, K. and Peck, G. E. (2001). Drug physical state and drugpolymer interaction on drug release from chitosan matrix films. Journal of Controlled Release, 75(1-2): 143153.

21. Kung, K.-H. (2006). Coordination complexes of p-Hydroxybenzoate on Fe oxides. Clays and Clay Minerals, 37(4): 333-340.

22. Arellano, I. H. J., Guarino, J. G., Paredes, F. U. and Arco, S. D. (2011). Thermal stability and moisture uptake of 1-alkyl-3-methylimidazolium bromide. Journal of Thermal Analysis and Calorimetry, 103(2): 725-730.

23. Song, Y., Xia, Y. and Liu, Z. (2012). Influence of cation structure on physicochemical and antiwear properties of hydroxyl-functionalized imidazolium bis(trifluoromethylsulfonyl)imide ionic liquids. Tribology Transactions, 55(6): 738-746. 
24. Montanino, M., Carewska, M., Alessandrini, F., Passerini, S. and Appetecchi, G. B. (2011). The role of the cation aliphatic side chain length in piperidinium bis(trifluoromethansulfonyl)imide ionic liquids. Electrochimica Acta, 57(1): 153-159.

25. Oyeyemi, V. B., Keith, J. A. and Carter, E. A. (2014). Trends in bond dissociation energies of alcohols and aldehydes computed with multireference averaged coupled-pair functional theory. Journal of Physical Chemistry A, 118(17): 3039-3050.

26. Gordon, M. H., Paiva-Martins, F. and Almeida, M. (2001). Antioxidant activity of hydroxytyrosol acetate compared with that of other olive oil polyphenols. Journal of Agricultural and Food Chemistry, 49(5): 24802485. 